\title{
Employing airborne lidar and archaeological testing to determine the role of small depressions in water management at the ancient Maya site of Yaxnohcah, Campeche, Mexico
}

\author{
Jeffrey L Brewer ${ }^{\mathrm{a}, *}$, Christopher Carr ${ }^{\mathrm{a}}$, Nicholas P. Dunning ${ }^{\mathrm{a}}$, Debra S. Walker ${ }^{\mathrm{b}}$, Armando Anaya Hernández ${ }^{\mathrm{c}}$, \\ Meaghan Peuramaki-Brown ${ }^{\mathrm{d}}$, Kathryn Reese-Taylor ${ }^{\mathrm{e}}$ \\ a Department of Geography, University of Cincinnati, Cincinnati, OH, USA \\ b Florida Museum of Natural History, Gainesville, FL, USA \\ c Centro de Investigaciones Históricas y Sociales, Universidad Autonóma de Campeche, Campeche, Mexico \\ d Centre for Social Sciences, Athabasca University, Athabasca, Alberta, Canada \\ e Department of Anthropology and Archaeology, University of Calgary, Calgary, Alberta, Canada
}

\section{A R T I C L E I N F O}

\section{Article history:}

Received 30 October 2016

Received in revised form 20 March 2017

Accepted 20 March 2017

Available online $\mathrm{xxxx}$

\section{Keywords:}

Ancient Maya

Lidar

Archaeology

Water management

Hydrologic analysis

\begin{abstract}
A B S T R A C T
High-resolution airborne lidar has been employed in the Maya lowlands to examine landscape modifications, detect architectural features, and expedite and expand upon traditional settlement surveys. Another potentially beneficial-and to-date underutilized-application of lidar is in the analysis of water management features such as small reservoirs and household storage tanks. The urban center of Yaxnohcah, located within the Central Karstic Uplands of the Yucatan Peninsula, provides an ideal test case for studying how the residents of this important Maya community managed their seasonally scarce water resources at the household scale. We employ an integrative approach combining lidar-based GIS analysis of $24 \mathrm{~km}^{2}$ of the site area, ground verification, and excavation data from five small depressions to determine their function and the role they may have played in water management activities. Our research shows that some, but not all, small depressions proximate to residential structures functioned as either natural or human-made storage tanks and were likely an adaptive component of expanding Middle Preclassic to Classic period urbanization at the site. Thus, while lidar has revolutionized the identification of topographical features and hydrologic patterns in the landscape, a combination of ground verification and archaeological testing remains necessary to confirm and evaluate these features as potential water reservoirs.
\end{abstract}

(C) 2017 Elsevier Ltd. All rights reserved.

\section{Introduction}

In this paper we discuss the application of airborne lidar (Light Detection and Ranging) for the detection and hydrologic analysis of closed depressions supported by the subsequent ground verification and archaeological testing of five of these features at the ancient Maya site of Yaxnohcah in southern Campeche, Mexico. Our goal in studying these depressions was to develop a scheme for identifying closed depressions in the lidar imagery and to determine whether or not they functioned as water storage features. If they did serve in a water management capacity, we also sought to understand the nature of these functions based on data recovered through archaeological excavation.

Lidar is a remote sensing technique that uses pulsed returns from an aircraft-mounted laser to measure distance to ground surface and can

\footnotetext{
* Corresponding author.

E-mail address: brewerjy@mail.uc.edu (J.L. Brewer).
}

detect features either indistinguishable or, in some cases, inaccessible through traditional field survey methods. Since its initial application in the Maya lowlands as part of the Caracol Archaeological Project (Chase et al., 2011), lidar has proven to be an extremely useful component of interdisciplinary studies seeking to understand the complex interrelationship between settlement, urbanism, and ecological adaptations to local environments. Despite being employed in multiple contexts, including land-use and land cover mapping (McCoy et al., 2011; Parent et al., 2015), hydrological (Pe'eri and Philpot, 2007; Brzank et al., 2008; Turner et al., 2014), and archaeological applications (Devereux et al., 2008; Gallagher and Josephs, 2008; Corns and Shaw, 2009; Evans et al., 2013; Johnson and Ouimet, 2014), not until its inclusion in the Caracol project did the benefits of lidar to studies of the ancient Maya landscape become realized. In particular, the ability of this technology to penetrate the dense tropical canopy and record the contour of the ground has proven extremely useful to Maya archaeologists seeking to locate, identify, record, and investigate a variety of natural and cultural features. 
In addition to the ongoing work at Caracol (Chase et al., 2014), recent projects in the Maya area-ranging from mapping the site of Mayapán (Hare et al., 2014), to measuring the effects of ancient Maya land use on contemporary forest canopy (Hightower et al., 2014), to assisting landscape archaeology studies (Hutson, 2015; Prufer et al., 2015)-have utilized lidar to examine various facets of ancient Maya settlement and ecology. Despite these advances, an underutilized aspect of lidar application in the Maya area is in the study of water management, specifically the analysis of how a society captures, controls, stores, and distributes water resources. Landscape archaeology studies, including those analyzing various aspects of water management, have traditionally relied upon topographic maps derived from field survey and mapping to study patterns and processes of water management, a labor intensive process that can take multiple years to complete (c.f. Carr and Hazard, 1961; Carr et al., 2015; Scarborough and Gallopin, 1991). A major advantage of employing lidar in such studies is its ability to supply the topographic detail necessary for greatly expedited multi- scale hydraulic analysis (c.f. Chase et al., 2010, 2011, 2014). A more holistic understanding of the physical, temporal, and spatial characteristics of these hydraulic features is necessary in order to understand their precise roles in the daily lives and activities of community inhabitants. The volume of spatial data provided by lidar is also extremely useful in compiling a catalogue of both large and small depressions that can then be examined on the ground (ground-truthed) and analyzed in terms of their water management capabilities.

An important consideration in this study is that, as opposed to simply considering all small depressions as household-scale water reservoirs, we attempt to determine their most likely function based on the physical and cultural data provided by archaeological excavation. Small depressions are ubiquitous throughout the Maya lowlands and have been shown to serve a variety of cultural functions in addition to water storage, including limestone quarries and clay or sascab (calcareous marl) mines (Folan, 1982; Tourtellot and Rose, 1993; Weiss-Krejci and Sabbas, 2002); areas of specialized agriculture, horticulture, and apiculture (Folan, 1983;

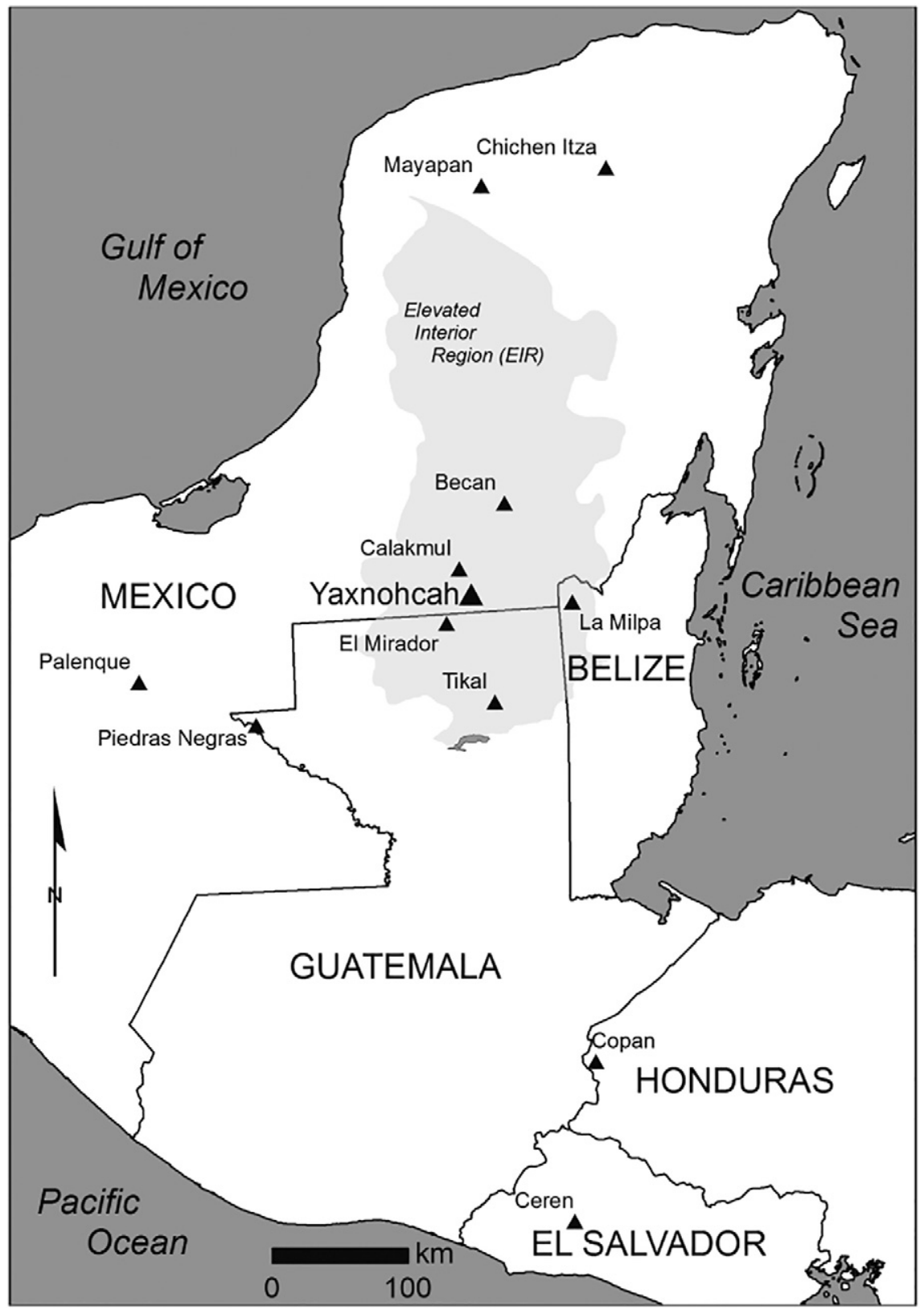

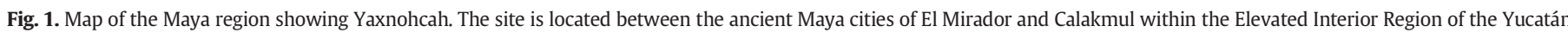
Peninsula, Mexico. 


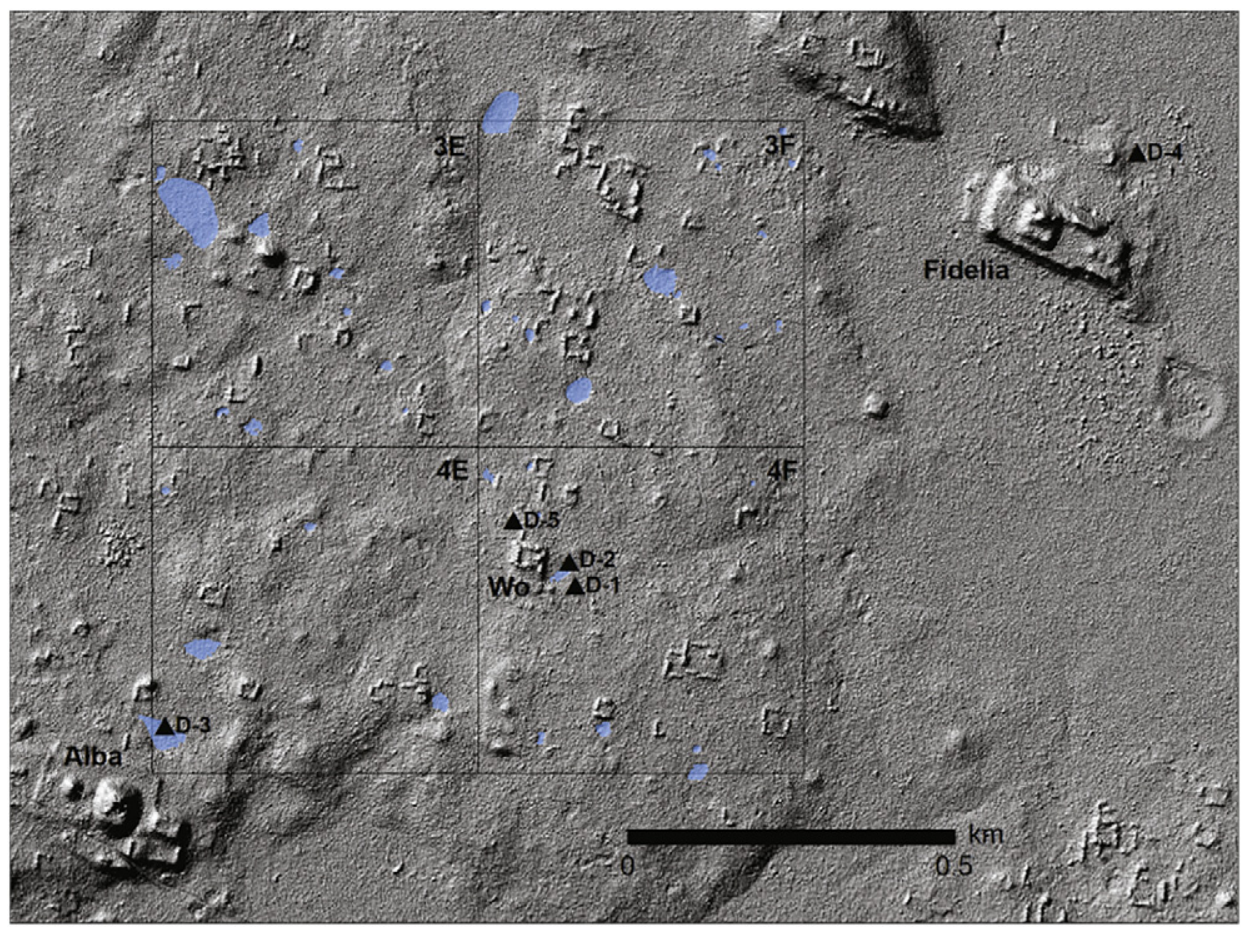

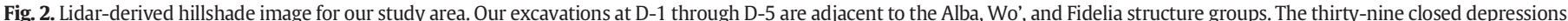

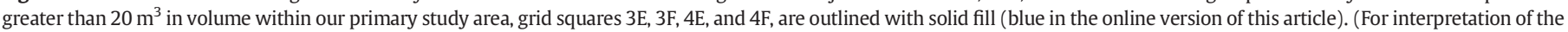
references to color in this figure legend, the reader is referred to the web version of this article.)

Gómez-Pompa et al., 1990; Kepecs and Boucher, 1996); and refuse dumps (Weiss-Krejci and Sabbas, 2002). Depressions can also originate naturally as sinkholes (dolines), which are a common phenomenon in karst systems and often occur close together in high densities (Akpinar-Ferrand et al.,
2012; Jennings, 1985; Hughbanks, 1995; Lene, 1997; Siemens, 1978). Following lidar analysis and ground-truthing of the small depressions, our primary focus was on determining the water management capabilities of these residential scale features.

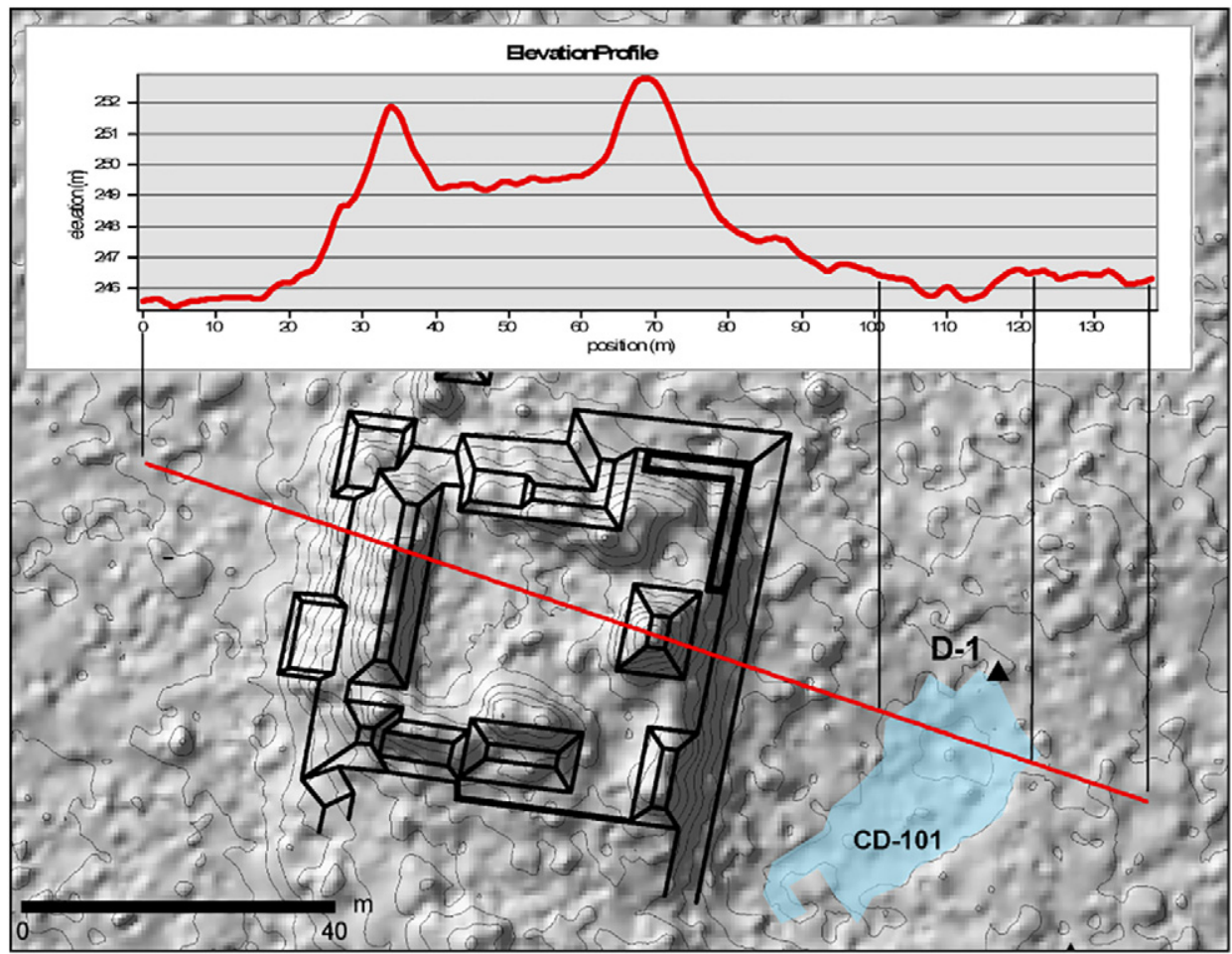

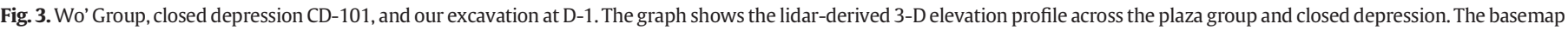

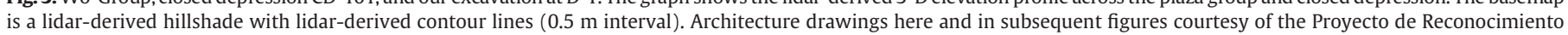
Arqueológico en el Sureste de Campeche, directed by Ivan Šprajc; Atasta Flores Esquivel and Thomaž Podobnikar surveyors. 


\section{Background: Yaxnohcah}

Yaxnohcah lies within the Elevated Interior Region of the Maya lowlands (Fig. 1), a karst physiographic province where natural perennial surface and accessible groundwater sources are negligible, making capture and collection of rainfall essential for year-round ancient human settlement (Dunning et al., 2012). Hence, the Maya took advantage of natural depressions, or created them as needed. The permeability of such depressions varied considerably, with natural clay sediments occurring in some, but with many floored with highly permeable limestone making sealing necessary for water storage.

Yaxnohcah is located at the southern end of the Calakmul Biosphere Reserve, situated beneath high tropical forests that form one of the highest and least disturbed tracts of continuous rainforest canopy in Mesoamerica. Karl Ruppert and John Dennison, Jr. initially visited the site in 1933 as part of the Carnegie Institute's Second Campeche Expedition, documenting portions of the site that they visited briefly. Their report described three major platforms, multiple courtyards and mounds, three chultuns, and at least one aguada, identified as Aguada Monterey (Ruppert and Dennison, 1943). Monterey served as the initial name for the site itself until 2004, when Iván Šprajc and colleagues revisited and investigated the site in detail, compiling fifteen maps in addition to assigning it the name Yaxnohcah-meaning "first big city" (Šprajc, 2008). Six large civic-ceremonial architectural complexes (designated Groups A-F) and two expansive elite residential groups were identified in this survey. The primary civic-ceremonial site core, containing the Alba, Brisa, and Carmela architectural complexes, is situated on a ridge overlooking the Bajo El Tomatal, while the Dolores, Eva, and Esma groups are located between $1 \mathrm{~km}$ east and southeast, partially surrounded by the bajo, a large seasonal swamp. The Fidelia group is located roughly $2 \mathrm{~km}$ northeast of the site core and is surrounded on three sides by the sprawling Bajo El Laberinto that borders the north and northeast sides of the site and continues northwest to the site of Calakmul (Reese-Taylor and Anaya Hernández, 2013).

The primary structure within every major civic-ceremonial complex measures at least $50 \mathrm{~m} \times 50 \mathrm{~m}$ in area and a minimum of $20 \mathrm{~m}$ in height. Structure Alba-1 in the Alba group represents the tallest construction at Yaxnohcah; the superstructures sit on a base that is $85 \mathrm{~m} \times 75 \mathrm{~m}$ in area and the tallest reaches $38 \mathrm{~m}$ in height (Reese-Taylor and Anaya Hernández, 2013, 2014). Review of the lidar imagery and associated ground verification by the Yaxnohcah Archaeological Project (YAP) (Reese-Taylor et al., 2016a, 2016b) have also shown public buildings to be widespread across the entire $24 \mathrm{~km}^{2}$ lidar area. In addition, the project has identified and mapped three additional monumental architectural groups: Grazia, Helena, and Irma (Anaya Hernández et al., 2016; Flores Esquivel, 2014; Reese-Taylor, 2014).

Based on ceramic data initially obtained by Šprajc (2008), the height of occupation at Yaxnohcah was estimated to have occurred between 600 BCE-400 CE and with a reflorescence from 750-950 CE. Dates obtained from ongoing ceramic analyses by YAP support these findings, further indicating that the site was continuously occupied from the early Middle Preclassic through to the end of the Classic period, followed by at least some Postclassic activity, possibly associated with regional pilgrimage (Walker, 2016). However, the number of triadic-style main structures-typical traits of the Middle and Late Preclassic (950 BCE$150 \mathrm{CE}$ ) suggest that most of the monumental buildings date to this period. Based on the quantity of civic-ceremonial architecture and the extent of the area over which it is spread, Yaxnohcah appears to be one of the larger Preclassic centers in the Maya lowlands.

\section{Data and methods}

\subsection{Lidar data acquisition and post-processing}

Closed depressions (potential reservoirs), were identified by analyzing the ground elevations derived from the lidar overflight of the site.

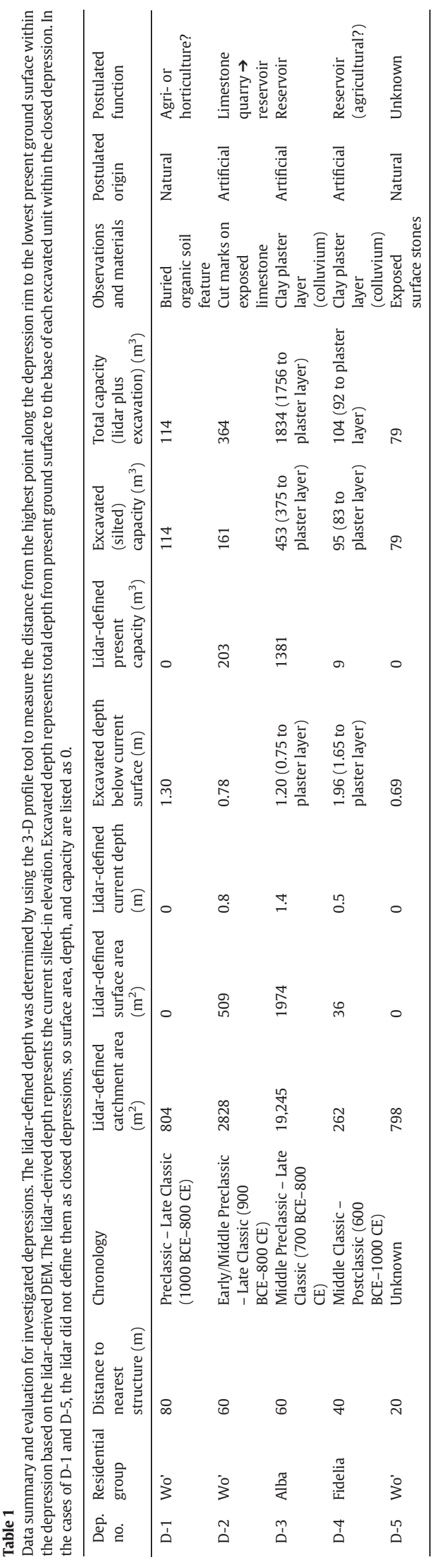


The list of closed depressions was the starting point for our field planning. Closed depressions are low spots in the landscape where water can pond. Features that had the appearance of a "blown out" dam (and which could be re-closed with the placement of a few stones) were also included on the potential list. The term "closed" refers to the elevation contour line forming a closed loop.

The lidar data collection was managed and conducted by the National Center for Airborne Laser Mapping (NCALM). Full details of the data collection and processing for this work and the broader Yaxnohcah Archaeological Project are discussed elsewhere (Reese-Taylor et al., 2016a, 2016b). The lidar data was collected with an Optech Gemini terrain mapping system set to a pulse repetition frequency of $125 \mathrm{kHz}$. The nominal shot density was 15 shots $/ \mathrm{m}^{2}$. The "classify ground" function of Terrasolid's TerraScan software was used to identify the ground points-nominally 1.5 returns $/ \mathrm{m}^{2}$. The ground returns were converted to a $0.5 \mathrm{~m}$ pixel DEM by Kriging. As is typically done in the Maya area, the "ground points" category includes both the ground surface and the ruins of ancient Maya structures.

Our search for closed depressions began with this DEM. The DEM was used to make a hillshade image and a elevation contour map using the GIS software ArcMap version 10 (ESRI) (Fig. 2). The hillshade and contour maps were visually inspected for closed depressions aided by computer-highlighting of contour lines between 35 and $200 \mathrm{~m}$ in length. A 3-D profile graph for each closed depression was also created to confirm that the contour lines represented a depression as opposed to a peak. The potential water holding capacity of each depression was calculated from the DEM derived area and depth. For closed depressions where a small dam would greatly increase the water holding capability, the capacity was calculated as if the eroded dam were replaced. The volume of the closed depressions ranged from $1 \mathrm{~m}^{3}$ to almost $4000 \mathrm{~m}^{3}$-some clearly too small to viably serve as water storage features. It should be noted that these volumes are based on the current ground elevations and that the depressions have certainly filled in from more than a thousand years of soil erosion, sedimentation, and soil development. For example, the top of D-1 (Fig. 3) is at $246.4 \mathrm{~m}$ elevation, with a current low point of $245.6 \mathrm{~m}$, resulting in a depth of $0.8 \mathrm{~m}$. Although the top contour line does not close the end of the depression, we hypothesize that the ancient Maya may have placed a small dam across the opening on the northeast side. The locations of the candidate aguadas (the closed depressions) and the lidar-derived hillshade map were transferred to a Garmin Map64 GPS for navigation in the field.

\subsection{Ground verification plan}

Our intent was to examine and evaluate closed depressions as potential reservoirs in areas where the project had, or was in the process of evaluating, data from residential structures (Brewer, 2016; Peuramaki-Brown et al., 2016). We specifically wanted to examine the link between residential structures and adjacent water storage tanks. To that end, prior to entering the field we inspected the lidar area for closed depressions in four of the $500 \mathrm{~m} \times 500 \mathrm{~m}$ project grid squares (squares 3E, 3F, 4E, and 4F; Fig. 2). Within that area, we identified 39 closed depressions with a potential water holding capacity of greater than $20 \mathrm{~m}^{3}$. This cutoff volume was somewhat arbitrary and takes into consideration post-use sedimentation. The number of closed depressions greater than $20 \mathrm{~m}^{3}$ in volume in each of the four grid squares was $11(3 \mathrm{E}), 14(3 \mathrm{~F}), 5(4 \mathrm{E})$, and 9 (4F). Many closed depressions have smaller capacities than this cutoff, but these were of secondary interest due to our assumption that they would have had limited use as household tanks.

In a few cases, closed depressions representing potential water storage features were discovered where no depression was identified in the DEM. These were always small depressions (shallower than the minimal detection limit of this method; less than approximately $30 \mathrm{~cm}$ deep) and/or appear to be located in sections of the lidar where low, dense vegetation obscured the ground surface (Fernandez-Diaz et al., 2014; Reese-Taylor et al., 2016a).

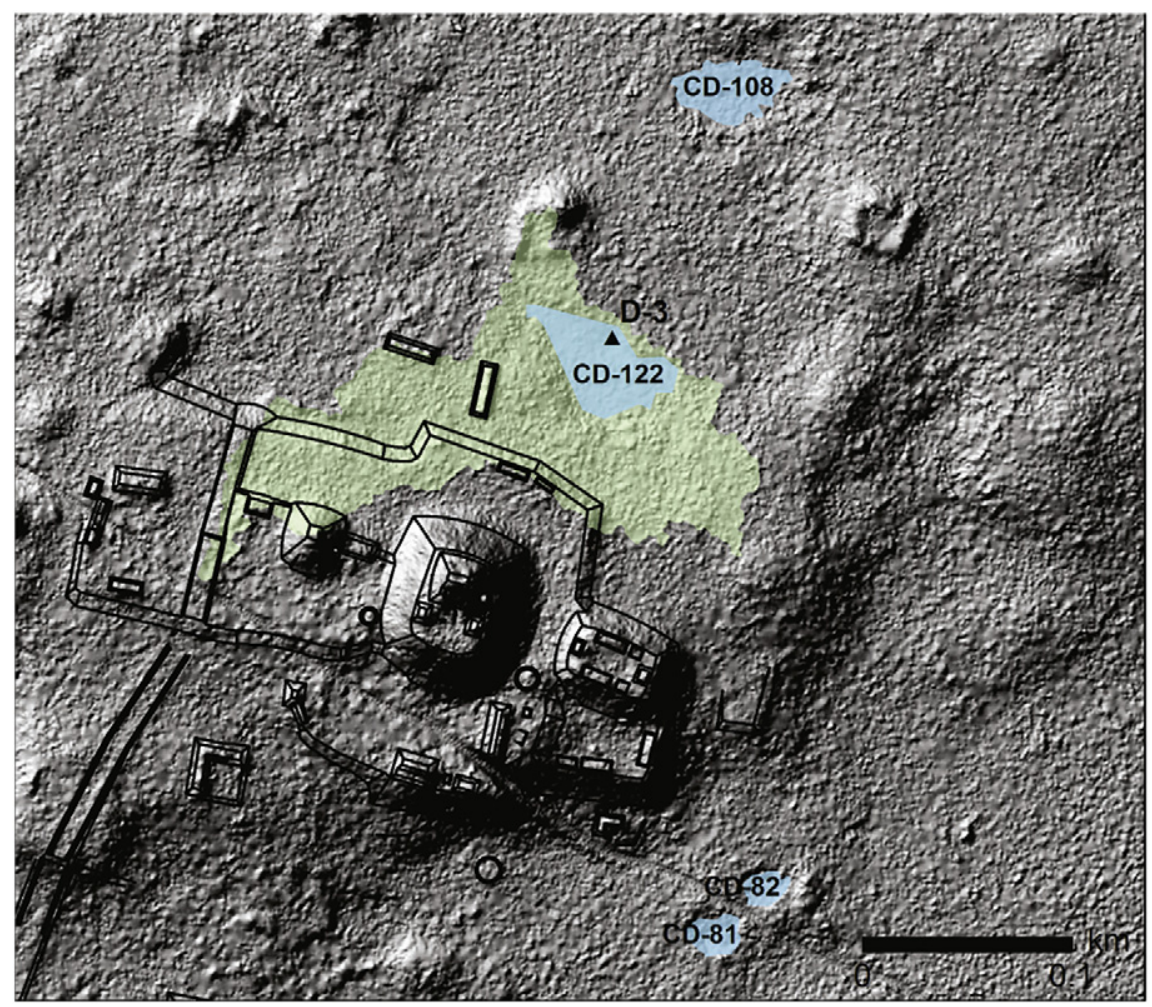

Fig. 4. The Alba Group and adjacent depressions. The operation group D-3 (Op-16 E, F, G, H, I, K) was positioned on the north berm of closed depression CD-122. 


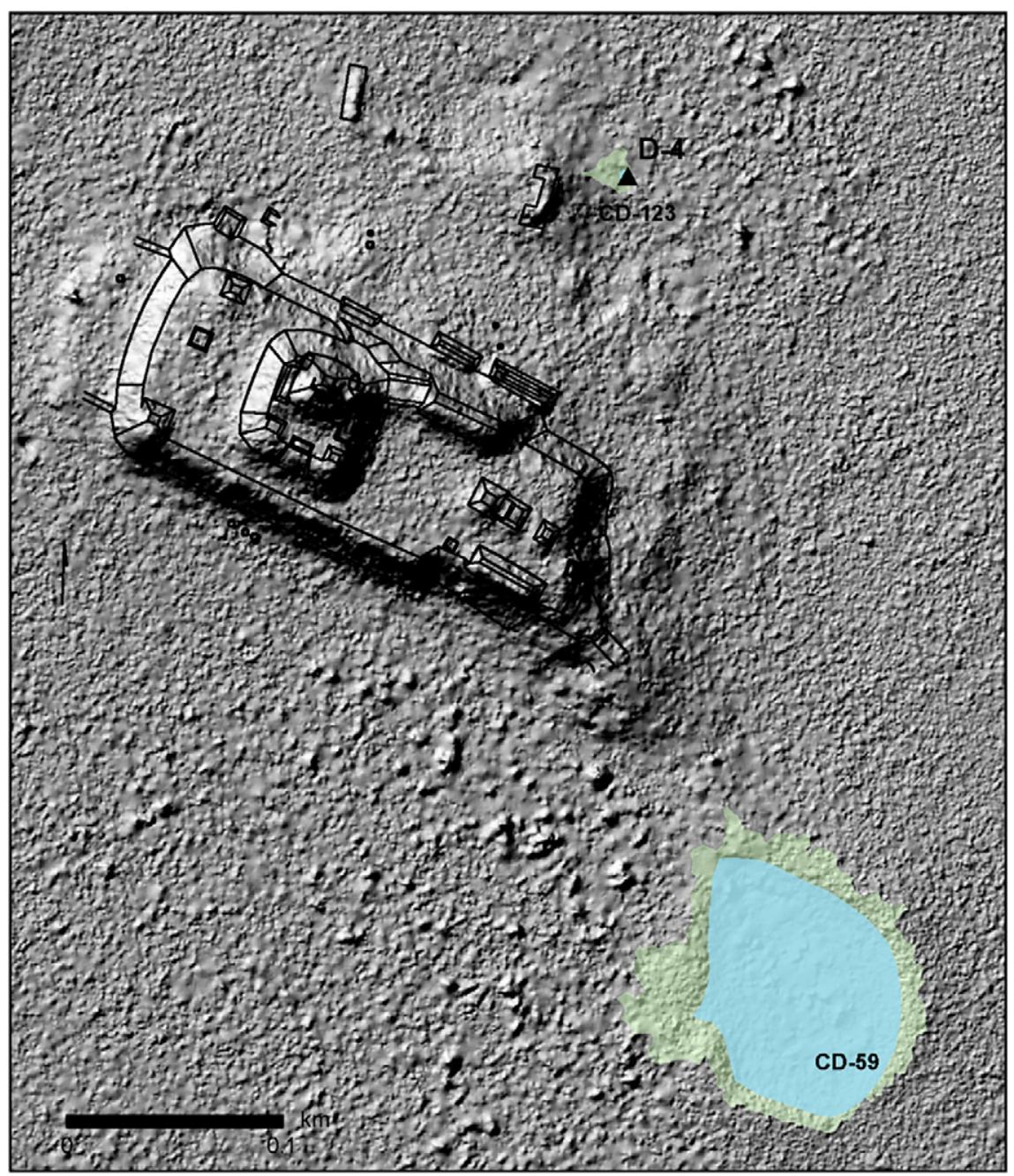

Fig. 5. The Fidelia Group on top of an extensively modified "island" in Bajo Laberinto. Our operation at D-4 is located in the center of closed depression CD-123.

\subsection{Archaeological excavation plan}

Although the pre-survey lidar analysis of the area between the Alba and Fidelia groups returned a total of 39 closed depressions with volume greater than $20 \mathrm{~m}^{3}$, the practical and logistical limitations of a five week field season necessitated the selection of a representative sample to test archaeologically. We sought to examine a sample of these features in terms of their physical dimensions as well as their spatial and (hypothesized) temporal characteristics. We used a GPS to guide us to the location of several $(\mathrm{N}=11)$ closed depressions for a visual inspection. From this reconnaissance we selected four areas for excavation-depressions D-1 to D-3 and D-5. Depression D-4 was located outside of the four pre-surveyed lidar blocks but was selected for investigation based on ground survey in an area on the north side of the Fidelia complex where previous test excavations of a potential agricultural field had taken place (Fig. 2 and Table 1). Although no residential data has been recovered from this area, the presence of an L-shaped mound adjacent to the northern edge of the depression supported our hypothesis that the feature may have served as a household reservoir.

While tested depressions were of varying dimensions, each was considered a residential scale feature and located within $80 \mathrm{~m}$ of a house mound or residential group in the peri-urban zone between Complexes Alba and Fidelia (a $0.5 \mathrm{~km} \times 1.8 \mathrm{~km}$ transect). This study area was selected due to our interest in potential spatial and temporal linkages between small domestic-scale reservoirs and residential groups. Since our intent was to tie together data from the residential excavations to that from the closed depressions, we selected three areas where the project had, or was gathering, data on residential occupation. Based on recovered ceramics, preliminary excavations had established primarily Preclassic and Classic period occupations at the Fidelia and Alba groups, respectively (Walker, 2016), and we sought to determine if potential water features spatially associated with these groups would exhibit similar date ranges for their construction and use.

Finally, we intentionally selected depressions of varying dimensions-including depth and surface area-to investigate any apparent correlations between these physical variables and the functional nature of the features. For example, did deeper depressions originate as limestone quarries prior to being utilized for water storage? Or did broader, shallower depressions appear to function in an agricultural capacity-perhaps to distribute water to, or collect runoff from, an adjacent agricultural field? The nature of the recovered geoarchaeological and cultural data would provide information on the probable functions of these closed depressions.

Depressions were excavated to bedrock or culturally-sterile sascab and all recovered ceramic material was assessed, assigned a preliminary date (if possible) based on the chronologic ceramic typology being developed for Yaxnohcah, and catalogued by the project ceramicist (Walker, 2016). These data would prove useful in establishing a date range for the active lifespan of these potential water features, as well as drawing parallels between their use and the occupation of adjacent 


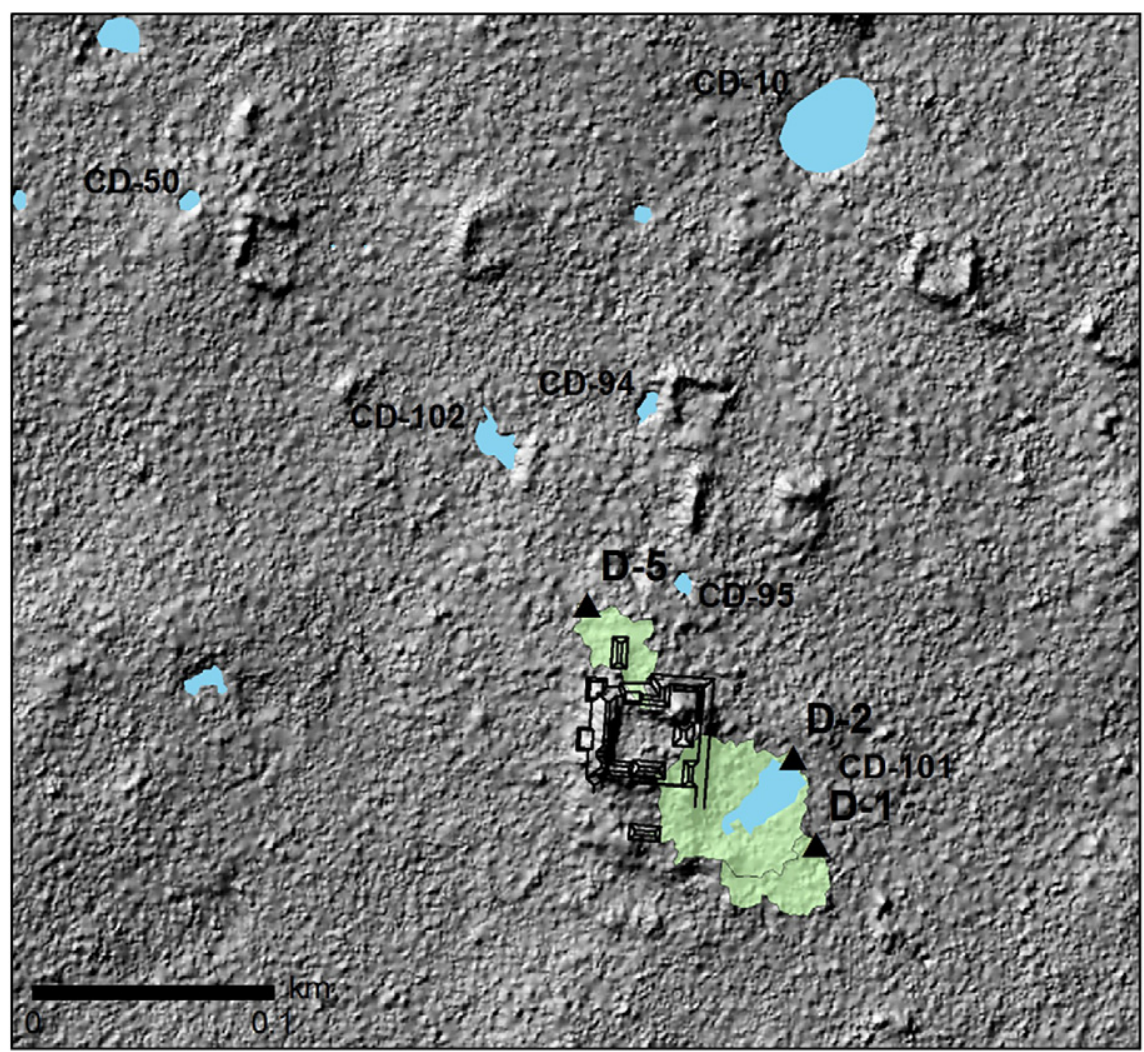

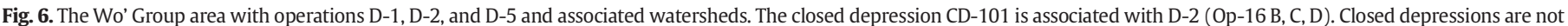
associated with D-1 (Op-16 A) and D-5 (Op-16 L). The six closed depressions in the image with volume greater than $20 \mathrm{~m}^{3}$ are labeled.

residential complexes. We also collected charcoal fragments from multiple depressions to submit for radiocarbon dating, although only one sample was considered substantial enough to test. Combined with ceramic material from the same unit, these data would be used to substantiate a chronology for the feature's active operation.

\section{Results and discussion}

\subsection{Assessment of depressions}

A combination of observations including the presence of catchments several times larger than the surface area, sufficient calculated capacity, and evidence of a clay or other sealant overlying the bedrock or sascab base of the depression were the key determinants in identifying depressions as domestic-scale reservoirs. This strategy is based on a similar scheme employed by Weiss-Krejci and Sabbas (2002) in their evaluation of small depressions as potential water features in the central lowlands and has since been applied in other studies of aguadas and small reservoirs in the Maya area (Akpinar-Ferrand et al., 2012; Brewer, 2007, 2016).

After GPS points were recorded from the center of each unit, excavations were initiated either in the center (Depressions D-1, D-3, and D-4) or along the rim (Depressions D-2 and D-5) of each depression tested. Excavations placed in the center focused on establishing a stratigraphic profile for the depression, as well as seeking evidence of a clay plaster sealant overlying the bedrock or sascab base of the depression or visible within the profile. A relatively impervious clay layer, whether naturally or artificially deposited, has been demonstrated to effectively reduce the porosity of the underlying limestone and aid in water retention at several sites throughout the lowlands (e.g. Beach and Dunning, 1997; Gill, 2000; Siemens, 1978; Scarborough et al., 1995). Remaining excavations were located along depression rims in an attempt to investigate the possible presence of a water retention or otherwise culturally-modified reservoir wall or of a channel that would have permitted the flow of water into or out of the reservoir. Such a channel was detected in an aguada near the site of La Milpa, where excavation revealed a natural depression modified to retain water that incorporated channel and berm features (Chmilar, 2005). During excavations of the Aguada Los Loros near the site of San Bartolo, Akpinar-Ferrand et al. (2012) identified a well-defined berm within a depression, the position of which suggested its use as a siltation tank for filtering water into the reservoir. Additional examples of these and similar practices exist elsewhere in the Maya lowlands.

Based on surface observations and recovered geoarchaeological data (Table 1), three of the five small depressions excavated at Yaxnohcah appear to have functioned as residential scale reservoirs at some point in their active lifespans. Depressions D-2, D-3, and D-4 were bordered by catchments that would have directed water into these tanks (Fig. 4 , Fig. 5, Fig. 6). Each had sufficient depth to store water, with measurements from present ground surface to exposed bedrock ranging from $0.78 \mathrm{~m}$ to $1.96 \mathrm{~m}$ and approximate capacities between 95 and $453 \mathrm{~m}^{3}$.

Reservoir capacity was estimated from two components: the current capacity of the closed depression based on the lidar DEM and the volume of sediment filling the postulated original ancient Maya depression. The potential capacity of the reservoir in ancient Maya time is the sum of the two capacities. The current capacity is estimated as one half the lidar-derived surface area times the lidar-derived maximum depth. The volume accounting for sedimentation is estimated by taking the formula for an elliptical cone, $\mathrm{H}(1 / 2) \Pi(\mathrm{A} / 2)(\mathrm{B} / 2)$, where $\mathrm{H}$ is the height and $A$ and $B$ are the length and width of the ellipse, respectively, and modifying it to accommodate the fact that small depressions tend to be more spherical in shape (Brewer, 2007). An important consideration with this calculation is that the maximum excavated depth or the depth of a sealed plaster surface or impermeable clay layer identified within each depression defines $\mathrm{H}$. This figure is based on the assumption that the ancient Maya would have excavated the depressions to their 


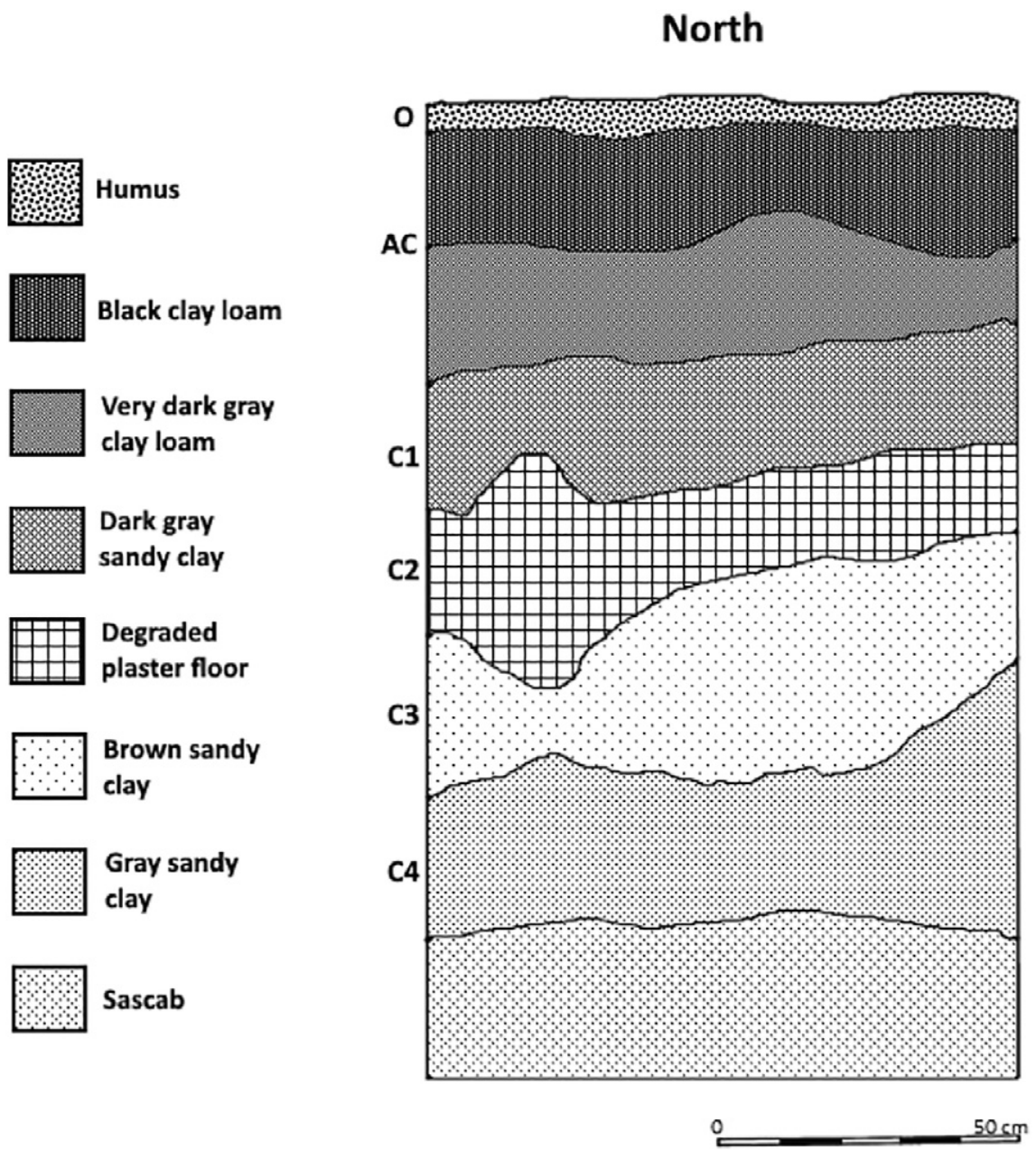

Fig. 7. Closed depression D-3 (Op. 16F) north profile showing remnants of clay layer overlying colluvium.

deepest extent in order to maximize their water storage capacity. In reality, each of the depressions investigated in this study contained a layer of in-washing sedimentation overlying the bedrock. The sealed plaster floors in Depressions D-3 and D-4 were placed on top of this sediment layer and would have represented the maximum utilized depth of these two features. This differs from the depth figure provided by the lidar (depth of present closed depression) and results in a significant difference between our lidar pre-screening volume estimates and our actual excavated volume calculation. This difference also accounts for more than one thousand years of sedimentation and soil formation taking place within the depressions. This is a notable distinction because it underlines the importance of excavating these depressions in order to fully understand their physical characteristics, as opposed to merely relying on the topographical profile provided by the lidar.

Importantly, evidence of former floors and superadjacent reservoir sediments was detected in the profiles revealed in Depressions D-3 (Fig. 7) and D-4 (Fig. 8). In D-4, the 3C horizon consists of the weathered remains of a floor constructed of hard-tamped clay mixed with sandy sascab (a technique still used today to line irrigation ditches and other hydraulic features in Yucatan). Above this floor, a thick layer of clayey reservoir sediments ( $2 \mathrm{C}$ horizon) accumulated over time along with broken ceramics and other artifacts. These sediments apparently experienced episodic seasonal desiccation as evident in the development of slickensides, a product of shrinking and swelling clay, which also produced distortion in the underlying floor. Either in the last years of its use, or post-abandonment, the depression began to fill with colluvial sediment (C-horizon) derived from the disintegration of the adjacent residential complex, atop which the modern soil has developed over a millennium. Depression D-3 likely originated as a quarry associated with the construction of the nearby enormous Alba Group monumental architecture, which subsequently partly filled with in-washing sediment ( $\mathrm{C} 3$ and $\mathrm{C} 4$ horizons), before being sealed with a now highly weathered plaster floor ( $\mathrm{C} 2$ horizon), then accumulated reservoir sediments ( $\mathrm{C} 1$ and AC horizons). Dates associated with ceramics recovered in both depressions coincided with dates derived from neighboring residential groups, supporting the idea that these reservoirs were in use during the occupation of these areas of the site.

Depression D-2 lacked evidence of a watertight surface. Based upon the exposed rock face on the depression rim and bedrock at the base of all three suboperations exhibiting cut marks on several limestone blocks, this feature appears to have initially functioned as a quarry for building material (Fig. 9). If limestone blocks were being mined for construction activity in the immediate vicinity, their most likely destination would be the Wo' Group residential complex currently under investigation by YAP (Peuramaki-Brown et al., 2016). Indeed, initial comparative analyses of ceramic material from this depression and excavations at the Wo' group indicate contemporaneity in Early and Late Middle Preclassic forms (Walker, 2016). This apparent temporal (and type) correspondence between ceramics from the residential and depression excavations, combined with the accessibility of the depression's location, support the notion that the area could well have functioned as a quarry for Middle Preclassic period building material at the Wo' Group before then serving as a water storage tank for the same community. Despite not being completely impermeable, the depression would nonetheless have been centrally located and readily accessible to serve local residents' immediate-possibly non-potable-water needs. The 


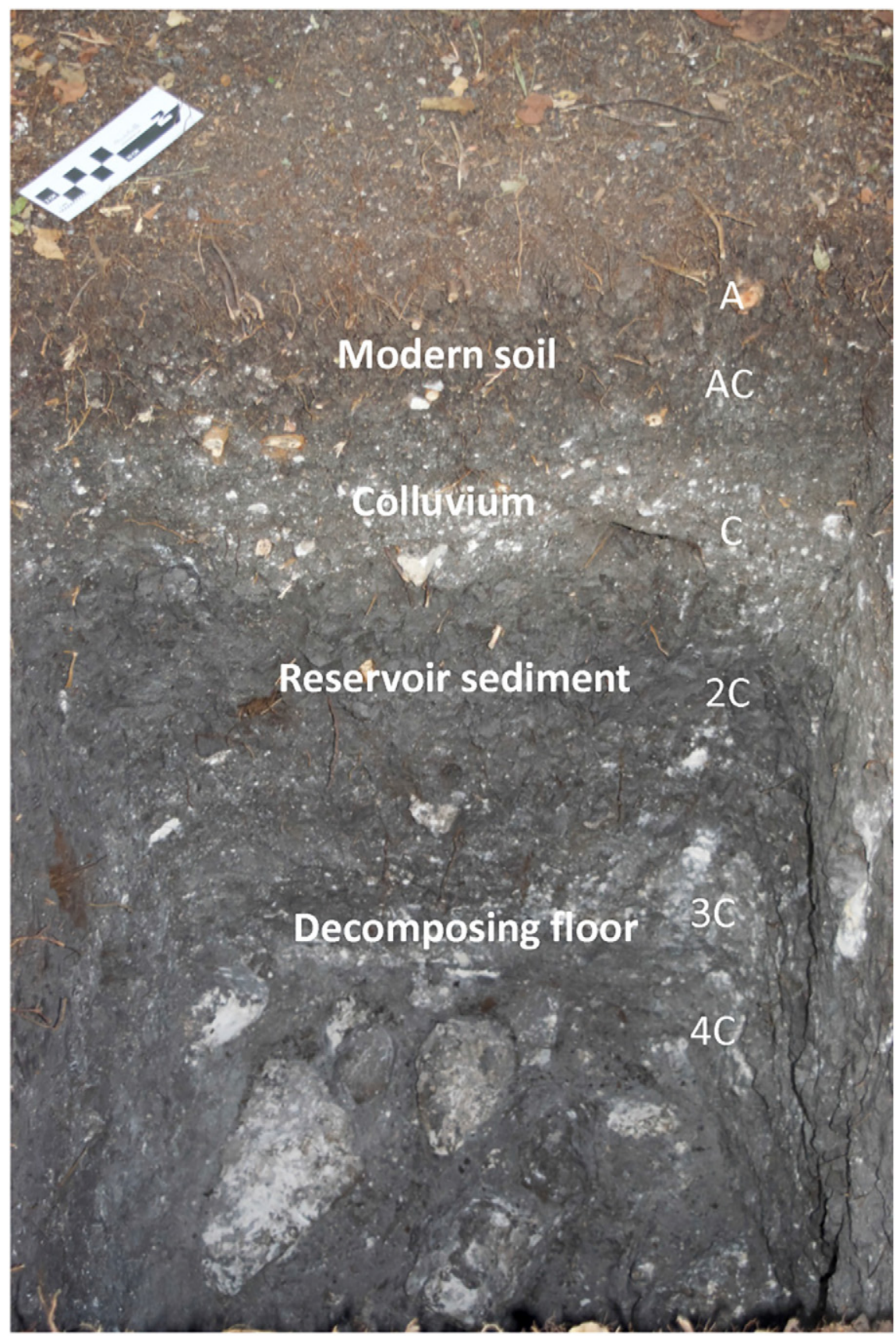

Fig. 8. Closed depression D-4 north profile showing remains of decomposing floor, colluvium and evidence of slickensides.

neighboring catchment area, in particular, would have been well placed to either shed runoff into or receive outflow from the reservoir, probably for agricultural purposes (Fig. 6). Similar depressions initially opened as quarries prior to their use as reservoirs have been identified elsewhere throughout the Maya lowlands (Folan, 1982; Weiss-Krejci and Sabbas, 2002).

In contrast, Depressions D-1 and D-5 appear to have originated naturally and presented little evidence of functioning in a significant water storage capacity. Both of these $1 \mathrm{~m} \times 1 \mathrm{~m}$ units were excavated to solid bedrock. Neither was located adjacent to a large catchment area, nor did they contain the remains of a clay sealant layer. However, Depression D1 did contain a circular indentation of loose, dark soil in the eastern edge of the north wall at a depth of approximately $45 \mathrm{~cm}$ below surface. With a diameter of $55 \mathrm{~cm}$, this "hole" also contained considerable buried organic material. Such pockets are known to be favored locations for Maya horticulture or arboriculture-activities that would undoubtedly have taken advantage of localized water shedding into the depression downslope from the adjacent Wo' Group. ${ }^{1}$

The role of small depressions as household gardens or areas of agriculture, horticulture, and apiculture have also been recognized elsewhere in Maya communities (Folan, 1983; Gómez-Pompa et al., 1990; Kepecs and Boucher, 1996; Lohse and Findlay, 2000). The chronological mix of recovered dateable ceramic material within Depression D-1 appears to indicate early and sustained (Preclassic through Classic period) activity in this area of the site-coinciding with occupation of the Wo' complex-which supports the idea this feature may have served as a long-standing agricultural plot during this period.

Depression D-5, located on the northern edge of the Wo' Group, contained a fairly high density of ceramic sherds, although all were

\footnotetext{
${ }^{1}$ This is only one possible interpretation. This buried depression may also result from a taproot or other natural subsurface feature.
} 


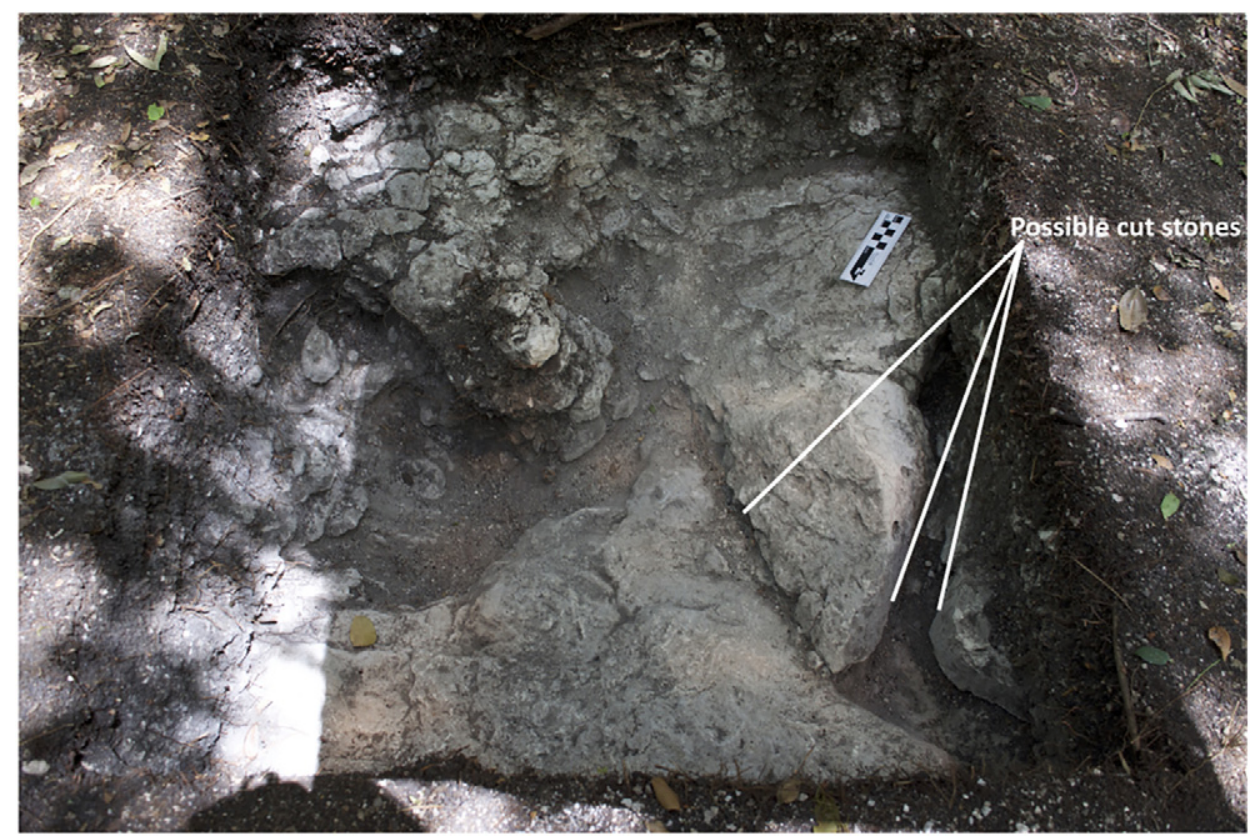

Fig. 9. Base of closed depression D-2 showing cut limestone blocks.

extremely eroded and unclassifiable. This depression appears to be an unmodified natural feature without any identifiable cultural function.

\subsection{Significance of results}

We examined five closed depressions that we hypothesized functioned in a water storage capacity within our study area at Yaxnohcah, but their origin and varying functions could only be tested through excavation. Selected through a combination of lidar analysis, ground verification, and spatial association with ongoing residential excavations in the vicinity of the Alba and Fidelia Complexes, these depressions presented a wealth of data regarding water management and other cultural activities during the Preclassic and Classic periods in this area of the site.

Not every depression is a cultural feature; indeed, only three of the five investigated in this study presented a definite cultural component. A combination of variables, including surface observations, storage capacity, and geoarchaeological evidence, was used to determine the likelihood of a depression functioning as a reservoir. Three of the five features studied-Depressions D-2, D-3, and D-4-present evidence of water storage activities. Conversely, Depressions D- 1 and D-5 appear to be naturally occurring features that lack the clay, plaster, or stone facing needed to improve their ability to hold water. As a result, these two depressions may have served less defined-and less reliable-water management or other functions or perhaps no cultural role at all. Depression D-1 presented some evidence of having served as an area for localized agriculture.

In the $1 \mathrm{~km} \times 1 \mathrm{~km}$ area we examined most closely (Fig. 2), we identified 39 closed depressions with a lidar-derived capacity greater than $20 \mathrm{~m}^{3}$. Extrapolating from this count, we would expect more than 900 closed depressions with volumes greater than $20 \mathrm{~m}^{3}$ throughout the entire $24 \mathrm{~km}^{2}$ lidar area. This very large number of closed depressions, potential reservoirs or household tanks should-in hindsight-not be unexpected. While many of the larger closed depressions appear to originate as natural karst sinkholes, we found that a greater number of the smaller depressions are holes left from quarrying limestone for building material. We assessed many of the closed depressions-including the very small ones-as quarries, based on exposed cut marks on the rim or walls and loose cut stones left in the hole. It is not surprising that the area is well covered with quarry holes, given the density of stone structures found across the upland surfaces in the lidar coverage area.

Although there continues to be an increasing recognition of the importance of water management in the growth and sustainability of Maya civilization, small reservoirs or tanks remain largely neglected as individual elements of systematic study within this larger system. Frequently occurring and widely dispersed throughout the Maya lowlands, these features have been shown to serve vital water collection, storage, and distribution functions at multiple scales within Maya communities. Confirming a water management function for these depressions, as well as determining additional cultural roles they may have served, provides essential knowledge in understanding the socioeconomic structure and day-to-day functionality of lowland Maya civilization. The comprehensive landscape-scale view provided by lidar is particularly beneficial to our understanding of these connections because it allows us to see the broader picture of water management-beyond the spatial limitations of archaeological transects, for example. In addition to identifying individual reservoirs adjacent to residential structures in the midst of dense tropical forest, the lidar permits us to visualize how these residential tanks may have operated apart from, or in tandem with, larger reservoirs or canals as part of a complex hydraulic system at Yaxnohcah.

\section{Conclusions}

Multiple studies conducted over the past few decades have emphasized the necessity of rainwater collection and storage as a critical aspect in the rise of Maya civilization (Adams, 1991; Dunning et al., 1999; Scarborough, 1993). More recently, lidar acquisition and analysis in the Maya area has begun to revolutionize landscape archaeology approaches to studying the urban and ecological adaptations of this adaptive, enduring culture (Chase et al., 2011; Chase et al., 2014; Johnson and Ouimet, 2014; Prufer et al., 2015; von Schwerin et al., 2016). Although the use of lidar in archaeology has enabled the expedient acquisition of spatial data over large areas and the detection of architectural and landscape features-including potential reservoirs-this study demonstrates that lidar analysis alone is unable to truly assess a community's residential-scale water management activities within the karst topography of the Maya lowlands.

Despite executing a successful sampling strategy and acquiring critical spatial, functional, chronological, and cultural data, broader goals of 
understanding the complex patterns of water management activities at Yaxnohcah-such as centralization versus decentralization and the degree to which water storage activities evolved during the Preclassic heyday of the community-have yet to be fully achieved. Ongoing water feature investigations, including Dunning's excavations at the larger Brisa and Fidelia reservoirs (Dunning et al., 2016), additional sampling of household-scale reservoirs, and possible testing of chultuns and their role in water storage, will be necessary to gain a more complete picture of the unified and adaptive system of water management that was undoubtedly operational at Yaxnohcah throughout the Preclassic and Classic periods of ancient Maya civilization.

\section{Acknowledgements}

We would like to thank Jerry Murdock and Venture Capital Partners for generously funding the lidar acquisition for the Yaxnohcah Archaeological Project. The lidar data was collected by the National Center for Airborne Laser Mapping (NCALM; NSF Award No. BCS-1261514). The work reported here was performed under permits extended to Kathryn Reese-Taylor and Armando Anaya Hernández for the YAP. Research was funded by National Science Foundation (NSF Award No. 1519015) and URGC (University of Calgary) grants, as well as ongoing support through the University of Calgary, Universidad Autonóma de Campeche, Athabasca University, and the University of Cincinnati. Special thanks go to the local field workers who assisted with the archaeological excavations detailed here, particularly Javier Cobos, Augustín Diaz, and Reyes Pérez Martínez.

\section{References}

Adams, R.E.W., 1991. Nucleation of population and water storage among the ancient Maya. Science 251, 632.

Akpinar-Ferrand, Ezgi, Dunning, Nicholas P., Lentz, David L., Jones, John G., 2012. Use of aguadas as water management sources in two Southern Maya Lowland sites. Anc. Mesoam. 23, 85-101.

Anaya Hernández, Armando, Peuramaki-Brown, Meaghan, Reese-Taylor, Kathryn (Eds.) 2016. Proyecto Arqueológico Yaxnohcah, Informe de las 2014 y 2015 Temporadas de Investigaciones. Mesoweb.

Beach, Timothy, Dunning, Nicholas, 1997. An ancient Maya reservoir and dam at Tamarindito, el Peten, Guatemala. Lat. Am. Antiq. 8 (1), 20-29.

Brewer, Jeffrey L, 2007. Understanding the Role of a Small Depression in Ancient Maya Water Management at the Medicinal Trail Site, Northwest Belize. M.A. thesis. Department of Anthropology, Division of Graduate Studies and Research of the University of Cincinnati.

Brewer, Jeffrey L, 2016. Investigaciones en Aguadas de Escala Residenciales. In: Anaya Hernández, Armando, Peuramaki-Brown, Meaghan, Reese-Taylor, Kathryn (Eds.) Proyecto Arqueológico Yaxnohcah, Informe de las 2014 y 2015 Temporadas de Investigaciones. Mesoweb, pp. 95-109.

Brzank, Alexander, Heipke, Christian, Goepfert, Jens, Soergel, Uwe, 2008. Aspects of generating precise digital terrain models in the Wadden Sea from Lidar-water classification and structure line extraction. Journal of Photogrammetry and Remote Sensing 63, 510-528.

Carr, Robert F., Hazard, James E., 1961. Map of the Ruins of Tikal, El Peten, Guatemala. Tikal Report No. 11. University Museum Monograph 21. University of Pennsylvania, Philadelphia.

Carr, Christopher, Weaver, Eric, Dunning, Nicholas P., Scarborough, Vernon L., 2015. Bringing the University of Pennsylvania maps of Tikal into the era of electronic GIS In: Lentz, David L., Dunning, Nicholas P., Scarborough, Vernon L. (Eds.), Tikal: Paleoecology of an Ancient Maya City. Cambridge University Press, Cambridge, pp. 59-86.

Chase, Arlen F., Chase, Diane Z., Weishampel, John F., 2010. Lasers in the jungle: airborne sensors reveal a vast Maya landscape. Archaeology 64 (4), 29-31.

Chase, Arlen F., Chase, Diane Z., Weishampel, John F., Drake, Jason B., Shrestha, Ramesh L., Clint Slatton, K., Awe, Jaime J., Carter, William E., 2011. Airborne LiDAR, archaeology, and the ancient Maya landscape at Caracol, Belize. J. Archaeol. Sci. 38, 387-398.

Chase, Arlen F., Chase, Diane Z., Awe, Jaime J., Weishampel, John F., Iannone, Gyles, Moyes, Holley, Yaeger, Jason, Brown, Kathryn, Shrestha, Ramesh L., Carter, William E., Diaz, Juan Fernandez, 2014. Ancient Maya regional settlement and inter-site analysis: the 2013 West-Central Belize LiDAR Survey. Remote Sens. 6, 8671-8695.

Chmilar, Jennifer A., 2005. Ancient Maya Water Management: Archaeological Investigations at Turtle Pond, Northwestern Belize. Unpublished M.A. thesis. Department of Anthropology, University of Cincinnati, Cincinnati.

Corns, Anthony, Shaw, Robert, 2009. High resolution 3-dimensional documentation of archaeological monuments \& landscapes using airborne LiDAR. J. Cult. Herit. 10S, $72-77$.

Devereux, B.J., Amable, G.S., Crow, P., 2008. Visualisation of LiDAR terrain models for archaeological feature detection. Antiquity $82,470-479$.
Dunning, Nicholas P., Anaya Hernández, Armando, Geovannini, Helga, 2016. Operaciones 13 y 19: Investigaciones en los Reservorios. In: Anaya Hernández, Armando, Peuramaki-Brown, Meaghan, Reese-Taylor, Kathryn (Eds.), Proyecto Arqueológico Yaxnohcah, Informe de las 2014 y 2015 Temporadas de Investigaciones. Mesoweb, pp. $110-121$

Dunning, Nicholas P., Scarborough, Vernon L., Valdez Jr., Fred, Luzzadder-Beach, Sheryl, Beach, Timothy, Jones, John G., 1999. Temple mountains, sacred lakes, and fertile fields: ancient Maya landscapes in Northwestern Belize. Antiquity 73, 650-660.

Dunning, Nicholas P., Beach, Timothy, Luzzadder-Beach, Sheryl, 2012. Kax and Kol: Collapse and resilience in lowland maya civilization. Proc. Natl. Acad. Sci. 109, 3652-3657.

Evans, Damian H., Fletcher, Roland J., Pottier, Christopher, Chevance, Jean-Baptiste, Soutif, Dominique, Tan, Boun Suy, Im, Sokrithy, Ea, Darith, Tin, Tina, Kim, Samnang, Cromarty, Christopher, De Greef, Stéphane, Hanus, Kasper, Bâty, Pierre, Kuszinger, Robert, Shimoda, Ichita, Boornazian, Glenn, 2013. Uncovering archaeological landscapes at Angkor using lidar. Proc. Natl. Acad. Sci. 110 (31), 12595-12600.

Fernandez-Diaz, Juan Carlos, Carter, William E., Shrestha, Ramesh L., Glennie, Craig L., 2014. Now you see it...now you don't: understanding airborne mapping LiDAR collection and data product generation for archaeological research in Mesoamerica. Remote Sens. 6 (10), 9951-10001.

Flores Esquivel, Atasta, 2014. Trabajos de reconocimiento y mapeo en Yaxnohcah, Campeche. Temporada de 2013. In: Reese-Taylor, Kathryn, Anaya Hernández, Armando (Eds.), Proyecto Arqueológico Yaxnohcah, 2013 Informe de la Segunda Temporada de Investigaciones. Mesoweb :pp. 12-15 November 1, 2014. 56 pp. http://www. mesoweb.com/resources/informes/Yaxnohcah2013.html.

Folan, William J., 1982. Mining and quarrying techniques of the lowland Maya. Anthropology 6, 149-174.

Folan, William J., 1983. Physical geography of the Yucatan Peninsula. In: Folan, William J., Kintz, Ellen R., Fletcher, Laraine A. (Eds.), Coba: A Classic Maya Metropolis. Academic Press, New York, pp. 21-48.

Gallagher, Julie M., Josephs, Richard L., 2008. Using LiDAR to detect cultural resources in a forested environment: an example from the Isle Royale National Park, Michigan, USA. Archaeol. Prospect. 15, 187-206.

Gill, Richardson Benedict, 2000. The Great Maya Droughts: Water, Life and Death. University of New Mexico Press, Albuquerque.

Gómez-Pompa, Arturo, Flores, José Salvador, Fernández, Mario Aliphat, 1990. The sacred cacao groves of the Maya. Lat. Am. Antiq. 1, 247-257.

Hare, Timothy, Masson, Marilyn, Russell, Bradley, 2014. High-density LiDAR mapping of the ancient city of Mayapán. Remote Sens. 6, 9064-9085.

Hightower, Jessica N., Christine Butterfield, A., Weishampel, John F., 2014. Quantifying ancient Maya land use legacy effects on contemporary rainforest canopy structure. Remote Sens. 6, 10716-10732.

Hughbanks, Paul J., 1995. Research at Guijarral (RB-18), In: Adams, Richard E.W., Valdez Jr., Fred (Eds.), The Programme for Belize Archaeological Project: 1994 Interim Report. The University of Texas at San Antonio, San Antonio, pp. 73-78.

Hutson, Scott R., 2015. Adapting LiDAR data for regional variation in the tropics: a case study from the Northern Maya Lowlands. J. Archaeol. Sci. Rep. 4, 252-263.

Jennings, Joseph N., 1985. Karst Geomorphology. Basil Blackwell, Oxford.

Johnson, Katharine M., Ouimet, William B., 2014. Rediscovering the lost archaeological landscape of southern New England using airborne light detection and ranging (LiDAR). J. Archaeol. Sci. 43, 9-20.

Kepecs, Susan, Boucher, Sylviane, 1996. The pre-Hispanic cultivation of Rejolladas and stone-lands: new evidence from Northeast Yucatán. In: Fedick, Scott L. (Ed.), The Managed Mosaic: Ancient Maya Agriculture and Resource Use. University of Utah Press, Salt Lake City, pp. 69-91.

Lene, Gene W., 1997. Geology of the Blue Creek Area. In: David Driver, W., Clagett, Heather L., Haines, Helen R. (Eds.), The Blue Creek Project: Working Papers From the 1996 Field Season. St. Mary's University, San Antonio, Texas, pp. 13-17.

Lohse, Jon C., Findlay, Patrick N., 2000. A classic Maya house-lot drainage system in northwestern Belize. Lat. Am. Antiq. 11 (2), 175-185.

McCoy, Mark D., Asner, Gregory P., Graves, Michael W., 2011. Airborne lidar survey of irrigated agricultural landscapes: an application of the slope contrast method. J. Archaeol. Sci. 38, 2141-2154

Parent, Jason R., Volin, John C., Civco, Daniel L., 2015. A fully-automated approach to land cover mapping with airborne LiDAR and high resolution multispectral imagery in a forested landscape. ISPRS J. Photogramm. Remote Sens. 104, 18-29.

Pe'eri, Shachak, Philpot, William, 2007. Increasing the existence of very shallow-water LIDAR measurements using the red-channel waveforms. IEEE Trans. Geosci. Remote Sens. 45 (5), 1217-1223.

Peuramaki-Brown, Meaghan, Morton, Shawn G., Castro, Ana, 2016. Operacíon 17 en el Grupo Wo', Excavaciones de Prueba en un Lote Doméstico Peri-Urbano. In: Anaya Hernández, Armando, Peuramaki-Brown, Meaghan, Reese-Taylor, Kathryn (Eds.), Proyecto Arqueológico Yaxnohcah, Informe de las 2014 y 2015 Temporadas de Investigaciones. Mesoweb, pp. 75-94

Prufer, Keith M., Thompson, Amy E., Kennett, Douglas J., 2015. Evaluating airborne LiDAR for detecting settlements and modified landscapes in disturbed tropical environments at Uxbenká, Belize. J. Archaeol. Sci. 57, 1-13.

Reese-Taylor, Kathryn, 2014. Resumen del Temporada 2013. In: Reese-Taylor, Kathryn, Anaya Hernández, Armando (Eds.), Proyecto Arqueológico Yaxnohcah, 2013 Informe de la Segunda Temporada de Investigaciones. Mesoweb, pp. 1-8 November 1, 2014.

Reese-Taylor, Kathryn, Anaya Hernández, Armando (Eds.), 2013. Proyecto Arqueológico Yaxnohcah, 2011 Informe de la Primera Temporada de Investigaciones. Mesoweb July 1, 2013. 92 pp. http://www.mesoweb.com/resources/informes/Yaxnohcah2011. html.

Reese-Taylor, Kathryn, Anaya Hernández, Armando (Eds.), 2014. Proyecto Arqueológico Yaxnohcah, 2013 Informe de la Segunda Temporada de Investigaciones. Mesoweb 
November 1, 2014. 56 pp. http://www.mesoweb.com/resources/informes/ Yaxnohcah2013.html.

Reese-Taylor, Kathryn, Anaya Hernández, Armando, Flores Esquivel, F.C. Atasta, Monteleone, Kelly, Uriarte Torres, Alejandro J., Acuña, Helga Geovannini, Carr, Chris, 2016a. Verificacion en Campo del Reconocimiento de Lidar. In: Anaya Hernández, Armando, Peuramaki-Brown, Meaghan, Reese-Taylor, Kathryn (Eds.), Proyecto Arqueológico Yaxnohcah, Informe de las 2014 y 2015 Temporadas de Investigaciones. Mesoweb, pp. 1-3.

Reese-Taylor, Kathryn, Anaya Hernández, Armando, Flores Esquivel, F.C. Atasta, Monteleone, Kelly, Fernández-Diaz, Juan Carlos, Uriarte, Alejandro, Carr, Christopher, Acuña, Helga Geovannini, Peuramaki-Brown, Meaghan, Dunning, Nicholas, 2016b. Boots on the ground at Yaxnohcah: ground truthing Lidar in a complex tropical landscape. Adv. Archaeol. Pract. 4 (3), 314-338.

Ruppert, Karl, Dennison, John H., 1943. Archaeological Reconnaissance in Campeche, Quintana Roo, and Petén. Carnegie Institution of Washington, Publication. 543 Washington, D.C.

Scarborough, Vernon L., 1993. Introduction. In: Scarborough, Vernon L., Isaac, Barry L. (Eds.), Economic Aspects of Water Management in the Prehispanic New World. JAI Press, Greenwich, Connecticut, pp. 17-69 Research in Economic Anthropology, supplement No. 7.

Scarborough, Vernon L., Gallopin, Gary G., 1991. A water storage adaptation in the Maya lowlands. Science 251, 658-662.

Scarborough, Vernon L., Becher, Matthew E., Baker, Jeffrey L., Harris, Garry, Jr, Fred Valdez, 1995. Water and land at the ancient Maya community of La Milpa. Lat. Am. Antiq. 6 (2), 98-119. von Schwerin, Jennifer, Richards-Rissetto, Heather, Remondino, Fabio, Spera, Maria Grazia, Auer, Michael, Billen, Nicholas, Loos, Lukas, Stelson, Laura, Reindel, Markus, 2016. Airborne LiDAR acquisition, post-processing and accuracy-checking for a 3D WebGIS of Copan, Honduras. J. Archaeol. Sci. Rep. 5, 85-104.

Siemens, Alfred H., 1978. Karst and the pre-Hispanic Maya in the Southern Lowlands. In: Harrison, Peter D., Turner II, B.L. (Eds.), Pre-Hispanic Maya Agriculture. University of New Mexico Press, Albuquerque, pp. 117-143.

Šprajc, Ivan, 2008. Reconocimiento Arqueológico en el Sureste del Estado de Campeche: 1996-2005. Paris Monographs in American Archaeology 19. BAR International Series 1742. Archaeopress, Oxford.

Tourtellot, Gair I.I.I., Rose, John J., 1993. More Light on La Milpa: Interim Report on the 1993 Season. Manuscript on file. Department of Archaeology, Boston University, Boston.

Turner, D.D., Ferrare, R.A., Wulfmeyer, V., Scarino, A.J., 2014. Aircraft evaluation of groundbased Raman Lidar water vapor turbulence profiles in convective mixed layers. J. Atmos. Ocean. Technol. 31, 1078-1088.

Walker, Debra S., 2016. Apuntes Sobre La Secuencia Cerámica de Yaxnohcah. In: Anaya Hernández, Armando, Peuramaki-Brown, Meaghan, Reese-Taylor, Kathryn (Eds.) Proyecto Arqueológico Yaxnohcah, Informe de las 2014 y 2015 Temporadas de Investigaciones. University of Calgary, Calgary, pp. 144-171.

Weiss-Krejci, Estella, Sabbas, Thomas, 2002. The potential role of small depressions as water storage features in the central Maya lowlands. Lat. Am. Antiq. 13 (3), 343-357. 